\title{
Oil, oil dispersants and related substances in the marine environment*
}

\author{
W. Gunkel \& G. Gassmann \\ Biologische Anstalt Helgoland (Meeresstation); \\ D-2192 Helgoland, Federal Republic of Germany
}

\begin{abstract}
Of all substances threatening life in the seas, oil has received by far the most attention from the public, administrators, politicians and scientists. The main reasons for this are: (1) even

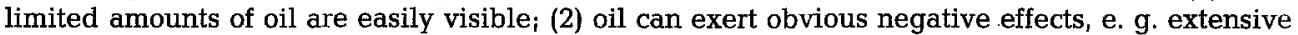
damage to birds and other animals, impairment of the recreational value of beaches and marinas, losses in fisheries due to tainting of catches and rejection by the public of seafood from areas known to have been recently polluted. In addition, dramatic tanker accidents are widely publicized. During the last decade tens of thousands of papers have been published about the impact of oil on the marine environment, and we are well informed about most basic facts, such as input and fate of oil, toxicity to adult organisms and recolonization. Due to considerable sophistication of analytical techniques, especially the introduction of glass-capillary gas chromatography, we are well aware that recently formed biogenic hydrocarbons by far extend the input directly due to pollution. Large gaps exist in our knowledge about sedimentation and transport of weathered oil, natural degradation rates, and the flow of hydrocarbons through the food web. Relatively little is known about the influence of oil and dispersants upon complex ecosystems. The often mentioned suspicion of increased cancer probability in humans due to seafood contaminated by hydrocarbons has not been substantiated $_{i}$ in fact, it seems unlikely that such an effect exists. By far the greatest uncertainty about potential oil impact concerns possible negative effects of hydrocarbons on chemical communication mechanisms between organisms. Intensive studies of behaviour scientists working with concentrations far below the toxic level are needed in fisheries biology, zoology and botany. Most cases of oil contamination known thus far have been limited in space and time; the oil has turned out to be degradable by natural processes. Such oil pollution neither endangers nor considerably impairs the future of mankind. In future research, more than anything else, objective critical evaluation and careful quantification are needed.
\end{abstract}

\section{INTRODUCTION}

Rapidly growing and developing branches of science make it necessary to compile and critically evaluate experimental results at increasingly shorter intervals. This requisite is especially important in fields where (1) research is very costly; (2) practical measures to be taken as a result of these investigations have financial consequences; (3) considerable public interests are at stake. All three points are applicable in the case of oil pollution of the sea.

* Dedicated to Dr. C. E. ZoBell, Professor emeritus Scripps Institution of Oceanography on the occasion of his $75^{\text {th }}$ birthday in recognition of his fundamental and outstanding contributions to marine microbiology and to our understanding of the role played by oil-degrading bacteria 
Many institutes in different parts of the world utilize a considerable research capacity to investigate oil pollution. There is very seldom an oil spill which does not attract numbers of biologists to record - mostly in a descriptive and qualitative way - the visible effects. But quantitative estimations or measurements regarding recovery potential are frequently not made.

It is common practice to document the results in voluminous reports which are beyond the capability of the experimental biologist to read, retain and judge; little effort is made to draw consequences or predict effects which may occur after a future oil spill.

It is said that scientific investigations are initiated with the interests of society at heart. However in many cases, one may suspect ulterior motives. For example oilpollution research is sometimes undertaken because (a) of easier availability of funds, (b) the field of pollution is "en vogue" and has a "progressive" image, (c) it provides an "opportunity" to criticize oil companies, administration and the establishment, and (d) one may occasionally appear on TV.

These approaches - together with a strong bias in regard to the effects to be expected and discussed - have assisted a widespread trivialization of an "environment science" whereby specialists have still to prove their usefulnes to society.

The task of the scientist must be to have an unbiased approach to the problem. He must always remember that, important as it is to investigate the most extreme situation at the site of the greatest effect, it is not justifiable to use such results to draw conclusions about the general effects on life in the sea, or even of a limited area of the sea. Such faulty interpretation of basically valid results, that is, generalizing on the basis of a particularly extreme instance, also occurs in other fields of science.

The basic facts about marine oil pollution and its effects are generally known to marine biologists. It is not intended here to go into simple background information nor to strive for completeness.

Short sections cover production and transportation of crude oil and the input into the marine environment. The fate of oil and the effects upon some groups of marine organisms and the recovery potential are stressed.

The main emphasis of this paper is on new methods, trends and results. Attention is drawn to gaps in research and incorrect conclusions. A condensed review of chemical possibilities and achievements to distinguish between fossil petroleum hydrocarbons and recently biogenically formed hydrocarbons is given.

\section{PRODUCTION AND TRANSPORT OF CRUDE OIL}

The present annual production of crude oil is about $3 \times 10^{9}$ tons, of which it is estimated that about 6 million tons, i. e. about $0.2 \%$, escapes into the sea as pollution. In all, from 1857 to $1978,55 \times 10^{9}$ tons were produced. Proven world reserves (1978) are about $88 \times 10^{9}$ tons (BP Ltd., 1979). Assuming constant pollution of $0.2 \%$ until the proven oil reserves are exhausted, we must expect a further burdening of the sea with about 176 million tons of oil.

The distribution of oil produced to date and the proven oil reserves is shown in Figure 1. Figure 2 shows the contrast between production and consumption in the various subcontinents; the great discrepancy here is the reason that massive amounts of oil have to be shipped over great distances across the sea. 


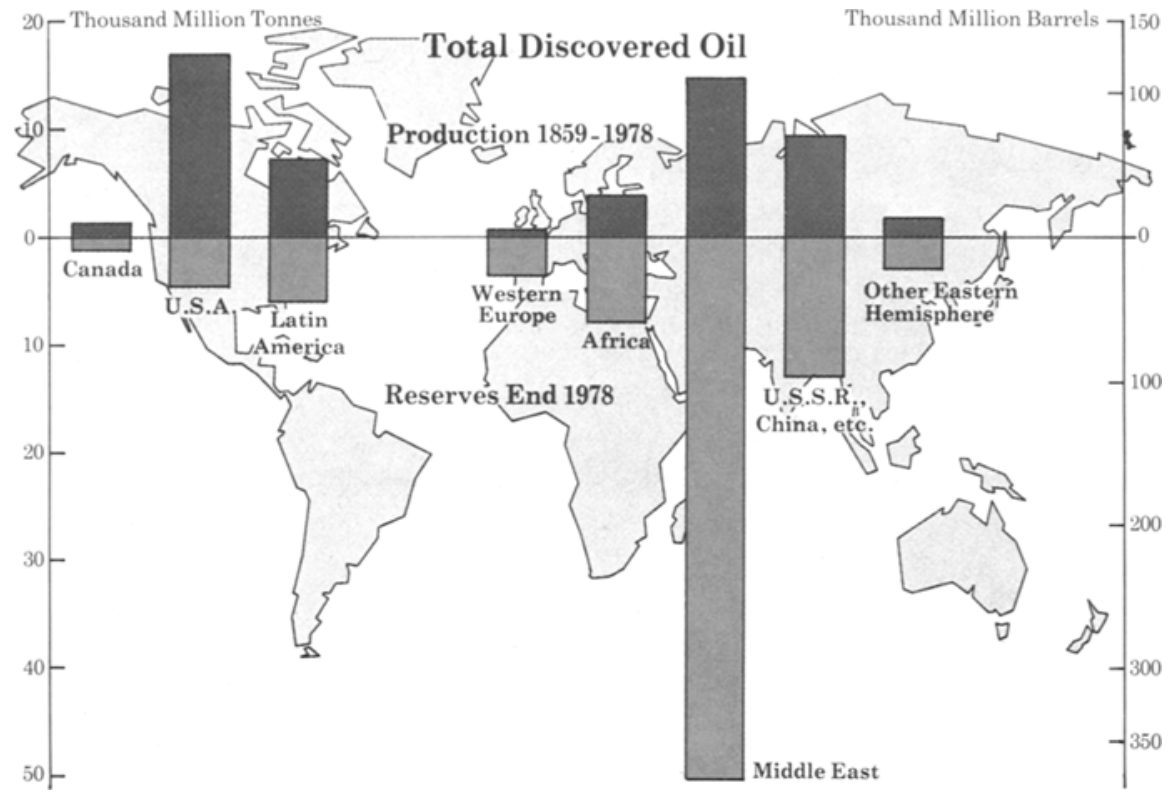

Fig. 1. Production of crude oil since 1857 and proven world oil reserves in billion tons 1978 (after BP Ltd., 1979)

\section{World Oil Production and Consumption 1978 Million Tonnes}



Fig. 2. World oil production and consumption 1978 (after BP Ltd., 1979) 
The flow of oil that was shipped by tanker in 1977 is shown in Figure 3. It is on these tanker routes particularly on the east coast of the U.S.A., the European west coast, South Africa, and the narrow passages to the Far East that most tanker accidents have occurred and future accidents are to be expected. Tanker accidents are by far the most spectacular oil spills, but they account, on average, for less than $5 \%$ or about 0.2 million tons of the total oil pollution of the sea per year.

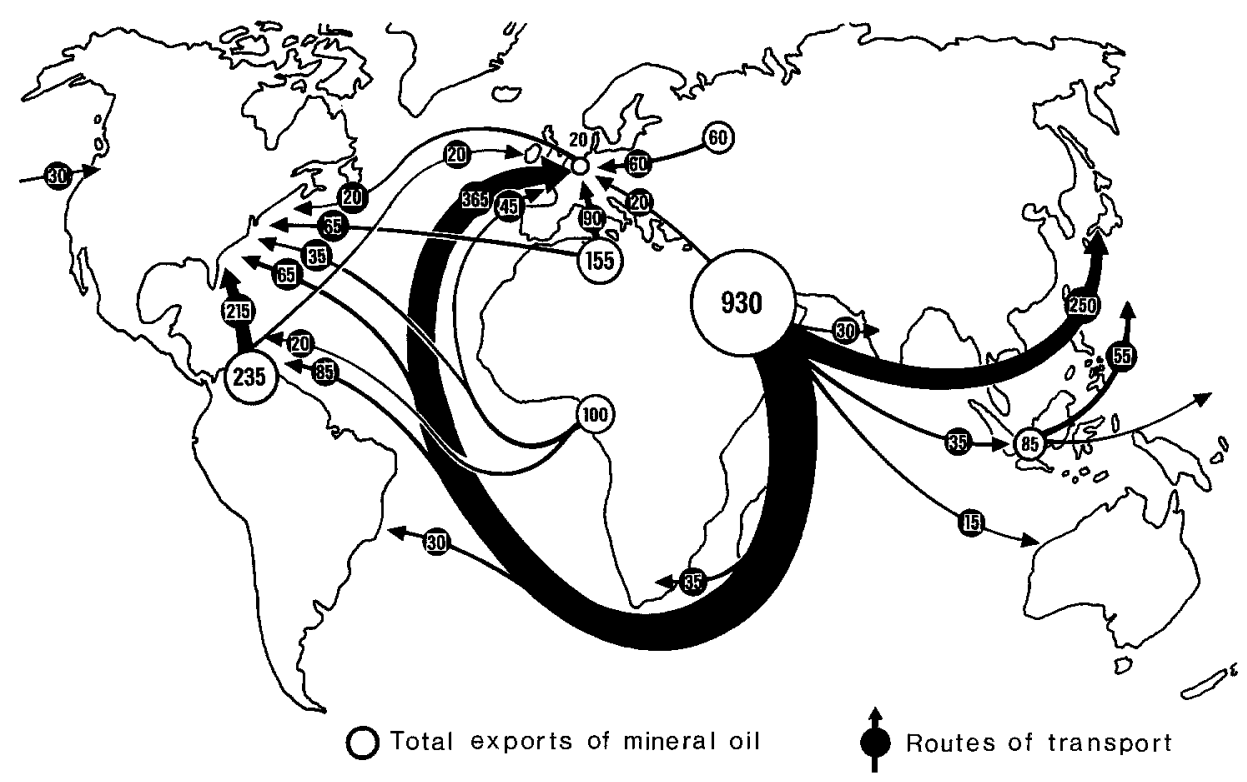

Fig. 3. World oil movement on sea lanes in million metric tons. (Quantities of less than 12.5 million tons are not taken into account.) The imports amounted to: USA and Canada 430, Western Europe 600, Japan 305 (modified after "Der Spiegel", 1979)

\section{OIL INPUT INTO THE MARINE ENVIRONMENT}

\section{Anthropogenic oil input}

Table 1 shows a key to the most important sources of oil input into the world oceans (IMCO/FAO, 1977). It is assumed that the amount of pollution has not changed appreciably in recent years. The same values can be found in several summaries. This agreement can be explained less by the fact that many workers have come to the same conclusions as a result of their research, than by the general acceptance of these figures. Global considerations, however, can only represent a first step: in order to come to a general understanding of the effects to be expected at present they are of little use.

For example, considered globally, we might have in sea water $1.4 \times 10^{12}$ tons of dissolved organic matter. With the introduction of $6 \times 10^{6}$ tons of fossil hydrocarbons, we obtain a ratio of fossil hydrocarbons to dissolved organic matter of about 1:200 000 . 
Table 1. Petroleum hydrocarbons entering the ocean

\begin{tabular}{|lc|}
\hline Sources & Annual amount (mio. $t$ ) \\
\hline Marine transportation & 1.93 \\
Tanker accidents & 0.2 \\
Offshore oil production & 0.08 \\
Coastal oil refineries & 0.2 \\
Industrial and municipal waste & 0.6 \\
River runoff & 1.6 \\
Urban runoff & 0.3 \\
Natural seeps & 0.6 \\
Atmospheric rainout & 0.6 \\
\hline Total & 6.11 \\
\hline
\end{tabular}

\section{Natural seepage}

It is estimated that about 0.6 million tons of oil enter the sea through seepages from the seabed (Koons \& Monaghan, 1976). Natural oil springs release a product which cannot be distinguished in any way from crude oil. However, since this oil enters the sea without any action on the part of humans, we cannot here speak of pollution.

\section{Recent biogenic hydrocarbons}

At least the same amount of hydrocarbons as that which enters the sea by pollution is being formed constantly in the sea by marine organisms (Koons \& Monaghan, 1976).

Marine organisms can contain up to $1 \mathrm{~g}$ of hydrocarbon per $\mathrm{kg}$ fresh weight. Assuming $50 \mathrm{mg}$ per $\mathrm{kg}$ fresh weight of plankton for an assumed primary production of $2 \times 10^{11}$ tons fresh weight annually $=2 \times 10^{10}$ organic C (Bunt, 1975), $1 \times 10^{7}$ million tons would be formed annually in the sea. This value, however, as a mean value is very probably an underestimate. Recent analyses of a large number of benthic algae in the Gulf of Mexico (Lytle et al., 1979) yielded a mean value of $100 \mathrm{mg} / \mathrm{kg}$. Evaluation of the great number of single analyses of hydrocarbon is made more difficult because commonly only individual chemical groups are determined, for example the easily measured alkanes. Hardy et al. (1977) assume a standing crop of 10 million tons of recent biogenic hydrocarbons in organisms. A large uncertainty factor is represented by the portion which comes into the sea via precipitation. It is estimated that from conifers alone approximately 200 million tons of terpene hydrocarbons enter the atmosphere in the form of microparticles (Went, 1960). With the present lack of data on analyses of precipitation, one has to depend on haphazard guesses. If $5 \%$ entered the sea, it would be 10 million tons per year. At a workshop of the National Academy of Sciences (1975) it was estimated that the amount of recent biogenic hydrocarbon that enters the sea with rainout is 2 to 3 orders of magnitude greater than the amount of fossil hydrocarbons which is introduced with precipitation. Thus these hydrocarbons represent the greatest uncertainty factor in any budget estimates. 


\section{FATE OF OIL}

The fate of oil in the sea has been described and reviewed repeatedly and has been the subject of many workshops, symposia and conferences (E. g.: ZoBell, 1964; Ruivo, 1972; National Academy of Sciences, 1975; American Institute of Biological Sciences, 1976; Gerlach, 1976; Wolfe, 1977; McIntyre and Whittle, 1977; American Petroleum Institute, 1977; Stevenson, 1978).

Figure 4 summarizes the events. After introduction there is first a marked spreading and immediately evaporation of the highly volatile substances begins. Within a few hours, as a rule, the portions which boil under $200^{\circ} \mathrm{C}$ have evaporated. The low-boiling aromatics dis s olve very easily in water and are subjected to dilution.

The oil $\mathrm{d} r$ if $\mathrm{ts}$ with the wind and currents. Through cl u m p ing, spray formation and the "bursting bubble effect" the continuous slick is broken up. Oil takes up water

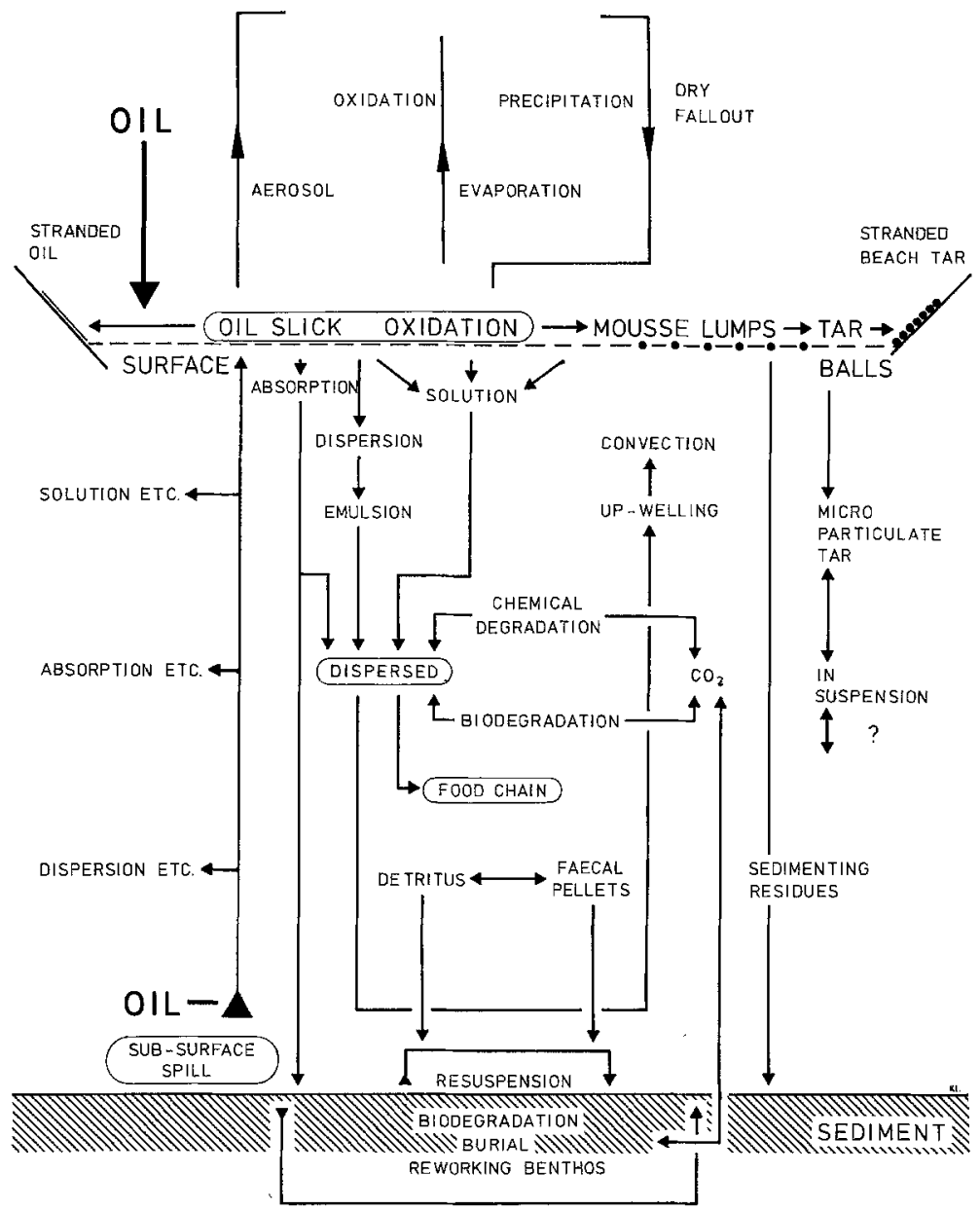

Fig. 4. A summary of the natural processes of dispersal and modification of oil in the marine environment (modified after Whittle et al., 1978) 
when clumping and as a rule forms oil-in-water emulsions, the so called "chocolate mousse". An oil slick on the open sea persists for a few days at most. This fact is of basic significance for the fate of the oil.

We can formulate as a firm rule: In the subsequent course of the oil spill we are dealing with oil in the form of particles and no longer in the form of a surface cover. Oil can be deposited on beaches at every stage of aging.

The most important factor which influences the persistence of oil on intertidal beaches is the mechanical energy available (Gundlach \& Hayes, 1978; Owens, 1978). While exposed beaches (high energy beaches) can be free of oil within 2 to 3 months even after heavy pollution, oil can persist for decades in salt marshes or tidal flats.

L ow energy shorelines normally are fine grained down to silt and mud. They generally have a high content of organic substances and are often anaerobic. Deposited oil can be buried or worked into the sediment. The reducing conditions slow the microbial degradation down to practically nil. Oil which has penetrated into the sediment can be influenced by changing water levels on tidal coasts: an exchange of water takes place and brings in new oxygen. Tidal action acts as a hydraulic pump at a slow rate and can therefore be responsible for the fact that oil flows out with the water and can be a nuisance for many years (Gebelein, 1973).

High energy shorelines in contrast are aerobic and continuously reworked. Stranded oil is mixed with inorganic material and rapidly particularized and displaced. The surface of the oil is thus enlarged and it is "diluted" by mixing with larger quantities of unpolluted sand and/or water. In beach areas as a rule the content of inorganic nitrogen and phosphorus compounds is higher than in open water. Thus oil is not only distributed, but the conditions are also very favourable for high activity of oil-degrading microorganisms. A further factor which plays a role in the persistence of the oil is whether the oil remains on the surface of the beach or penetrates it. The viscosity of the oil is important as well as the pore size and therefore the pore space of the beach. Treating the oil with surfactants can lead to deep penetration into the beach sediment.

\section{Pelagic oil}

The subsequent and ultimate fate of oil depends on whether it remains pelagically drifting in the open sea or whether it reaches a beach within a short period of time. The latest estimations of pelagic tar drifting at the surface are 36000 tons for the world oceans and 180 tons for the region of the North Sea (Koons \& Wheeler, 1977; Oppenheimer et al., 1977). It is assumed that in contrast to oil degradation in coastal areas, weathering and biodegradation at the surface of the tar balls is a slow process. It is very complicated to study. The surface of the tar balls is assumed to disintegrate to very small microparticles, thereby continually reducing the size of the lump. To what extent a part of the pelagic tar penetrates into the deep sea and eventually to the bottom has still not been elucidated and remains open to speculation. We are thus uncertain about the ultimate fate of a very considerable part of the oil pollution which enters the sea. The residence time of pelagic tar on the sea surface appears to be of the order of a year or more (Butler et al., 1973; Butler \& Morris, 1974). 


\section{Microbial oil degradation}

Although hydrocarbons can be degraded by higher organisms and algae, and photooxidation plays a part in the degradation of oil, the degradation is accomplished chiefly by microorganisms, bacteria playing the most important role. Several good and updated reviews are available (Fuhs, 1961; ZoBell, 1964, 1973; Floodgate, 1972; Crow et al., 1974; McKenzie \& Hughes, 1976; Bartha \& Atlas, 1977; Van der Linden, 1978).

Oil degraders are widely distributed. In over 1000 samples of water and sediment from tidal and offshore regions of the North Sea that we investigated (Gunkel, 1968, 1973; Oppenheimer et al., 1977; Gunkel et al., 1980) less than 10 contained no oil degraders. The highest numbers were in oiled sediments and drifting oil (up to $8 \times 10^{10}$ per liter). Up to now about 100 strains of oil-degrading bacteria have been described. Whenever an oil spill occurs it will inevitably be infected.

The multiplication potential of bacteria is unimaginably great and the textbook example is well known in which a single bacterium takes only 100 generations - which could be $50 \mathrm{~h}$ under optimal conditions - to form a mass the size of the earth. This multiplication is limited primarily by abiotic factors such as substratum, solubility and surface, temperature, oxygen content, inorganic nitrogen and phosphorus salts, interfering easily degradable organic substances and toxic concentrations of some hydrocarbons with low boiling points (Gunkel, 1967). As a rule oxygen is the main limiting factor of microbial growth and degradation in sediments. Nitrogen and phophorus salts exhibit this limitation in the open sea.

We are fairly well informed about the action of these limiting factors in laboratory experiments as we are about the potential of pure cultures. However, we are only beginning to learn about degradation rates in nature. Here are the greatest gaps in our understanding of the final fate of the oil.

Biodegradation has been overrated in the past years, in regard to the short-term effects. It has become increasingly evident that it is dispersal systems such as evaporation, dissolution, etc., rather than biodegradation, which remove the oil from the surface.

Biodegradation seems to be underrated with regard to its long-term effect, or in cases of chronic pollution. There are two mechanisms which have a fundamental significance for oil degradation and where investigations are badly needed.

\section{Multiplication of bacteria-eating Protozoa}

In enrichment cultures multiplication of bacteria-eating protozoa has been observed. This not only stops any further increase of the bacterial numbers, but drastically reduces the numbers of oil-degrading bacteria present. We have to assume that such processes, whereby high-value protein formed from the oil is channelled into the food web, also occur in nature. Much more research is needed here.

\section{Recalcitrance and cooxidation}

Some hydrocarbons are oxidized by microorganisms without supporting their growth. Another organic substance which might be a hydrocarbon acts as a cosubstrate. Cooxidations are known for cycloalkanes and chlorinated hydrocarbons. Although there is no advantage apparent for the enzyme-producing microorganism, commensals can benefit. Cooxidation is a mechanism of nature which can also lead to the degradation of substances which are not synthesized in nature (Horvath, 1972; Perry, 1979). 


\section{Seeding of oil spills}

One of the most questionable topics in microbiology and applied scientific knowledge for practical oil removal is the development of commercial inocula of hydrocarbon degraders. Seeding of oil spills will never be successfully applied because oil degradation is not inocula limited: it is limited by abiotic factors. This has been confirmed repeatedly (e. g. by Atlas \& Bartha, 1973). To foster hopes that a practical and applicable method can be developed to clean up large oil spills is wishful thinking if not malicious trickery.

\section{OIL DISPERSANTS AND RELATED SUBSTANCES}

The long controversial issue regarding the use of dispersants to combat oil spills has become less heated in recent years. The bad reputation of the dispersants was caused by the first generation of remedies which were used with toxic solvents. However, the use of non-ionic dispersants in water-soluble solvents, as dispersants of the second generation, will never be completely without problems (Blackman et al., 1978; Hellmann, 1978). The question of using dispersants for oil pollution in open water is so complex that an optimal strategy for their use must be worked out anew in each case. A dispersant has a toxic effect when the surface tension of the water is lowered beneath a certain limit. If one accepts the risk involved, it is only to obtain definite advantages.

These advantages are as follows: (1) the fixation of the oil from the surface to the body of water; this has clear advantages especially to the bird life; (2) an increase in the rate of microbial degradation.

These advantages, however, are limited by certain conditions: (1) only oils of low viscosity can be dispersed; (2) the addition of the dispersant and the mechanical energy for emulsifying must be technically possible within a very short time, since this is a race against the aging of the oil.

The disadvantages which weigh against the widespread use of dispersants are: (1) the hindrance of the desirable rapid evaporation of volatile oil components; (2) the suppression of the desirable tendency of oils to self-encapsulate and to form tar balls, whose formation is assumed to be the least dangerous form in oil pollution; (3) their employment only for relatively small oil spills.

Beside the uses of surface active agents mentioned above, a further variation in their employment has been developed recently (Dixon, 1977), the so-called "Oil Herder" or "Oil Marshal".

Instead of spreading the oil, the oil films are forced together. This accelerates the particularization, which is a desirable process since it changes the massive short-term contamination of the environment into a longer but less dangerous process.

All work about oil pollution is incomplete without a quantitative estimation of the causative agent: the oil.

\section{PROBLEMS IN CHEMICAL ANALYSIS}

The goal is to show that the given environmental pollution is definitely due to the oil which was spilled; this is often very difficult.

The difficulties arise from the fact that on the one hand the oil is an extremely complicated mixture of substances which will probably never be completely analyzed; 
on the other hand substances analogous to oil are present in the environment and are being continually formed, but they do not differ from the components of the oil itself. Certainly it is easy to determine the oil quantitatively when it is fresh in the environment; a balance scale is sufficient. The polluting source of the oil with its proof of identity is also relatively easy to determine. The so-called fingerprint techniques such as gas chromatography, infrared spectrometry, fluorescence spectrometry, metal content analysis are sufficient (see Fig. 5).

However, in order gravimetrically to determine not only beached or pelagic tar balls, but also their unknown origin, a highly developed "Multiparameter Oil Pollution Source Identification System" (Miller, 1973) is necessary.

In all other cases where one handles oil in invisible forms (such as dissolved traces) the techniques of analysis are no longer sufficient to determine the origin of the oil from the amount and components present. At this point one is no longer able to determine the oil in its entirety.

The components which belong specifically to the oil are mixed with recent biogenic hydrocarbons. Correctly speaking one may not throw these together in the same pot, because then the environmental pollution will appear to be higher due to the addition of the recent substances. In such cases it is necessary to make use of the most modern highly developed separation techniques in order to separate the mixtures into their components of fossil and recently formed hydrocarbons.

Without going into details, the method necessary for separating the groups is that of high-pressure liquid chromatography; for determining the individual substances the method of high-performance glass capillary gas chromatography $\left(\mathrm{GC}^{2}\right)$ is used, and for quantitative measurements of aromatics a high-resolution mass spectrometer.

Biogenic molecules tend towards a very definite configuration. This stereospecificity is lost during the maturation process of the initial biological substances into crude oil.

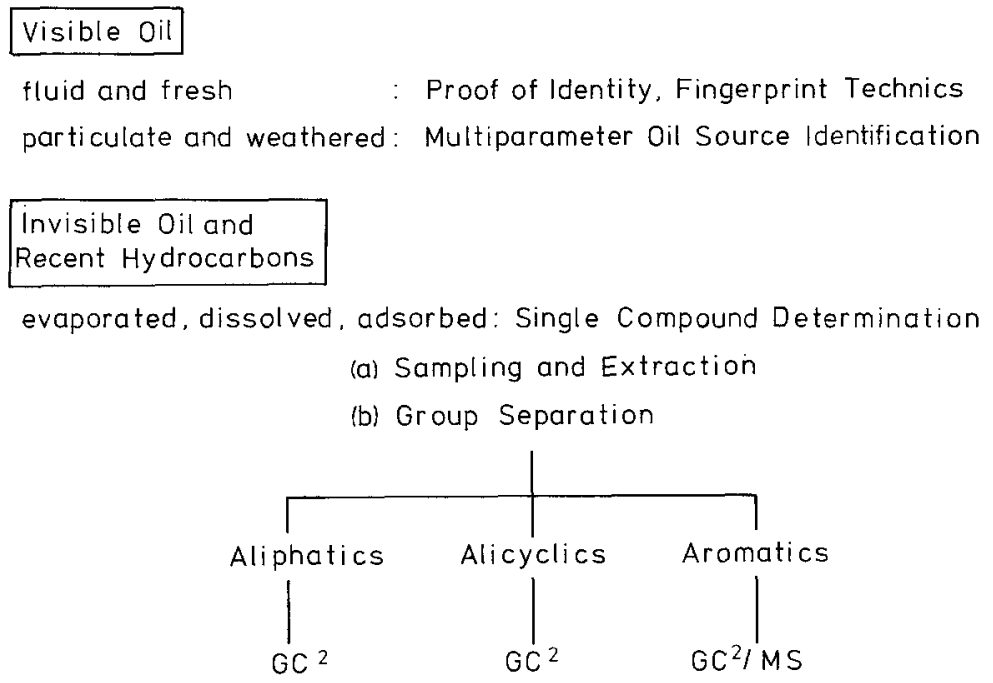

Fig. 5. Oil pollution evaluation system 
The other possible sterioisomeric molecules are formed by racemization. This has been demonstrated in the lower boiling range (Cox et al., 1972; Patience et al., 1978) of a hydrocarbon mixture with the diasteriomeric isoprenoid alkanes: 2,6, 10 - trimethyltetradecane $\left(2,6,10-C_{17}\right)$, norpristane (norpri), pristane (pri) and phytane (phy) - and for the upper boiling range, for the diastereoisomeric steranes: the cholestanes and hopanes Dastillung \& Albrecht, 1976). Using as an example a glass-capillary gas chromatogram of the aliphatic and alicyclic fraction of Ekofisk oil may explain this phenomenon. As seen in Figure 6 the chromatogram of the n-alkanes has several peaks which are noticeable by their size and symmetry. In between are the cycloalkanes and isoalkanes. Among these are the $C_{17}$ to $C_{20}$ isoprenoid alkanes. These are easily recognized as double peaks. The second subpeaks represent the original biogenic, stereospecific molecule, from which the other possible configurations are formed - here in the first subpeaks - through the epimerization process. These double peaks are an unmistakable sign of a fossil contamination. From these, it is possible to determine the fossil part of an environmental hydrocarbon mixture.

\section{OV 101}

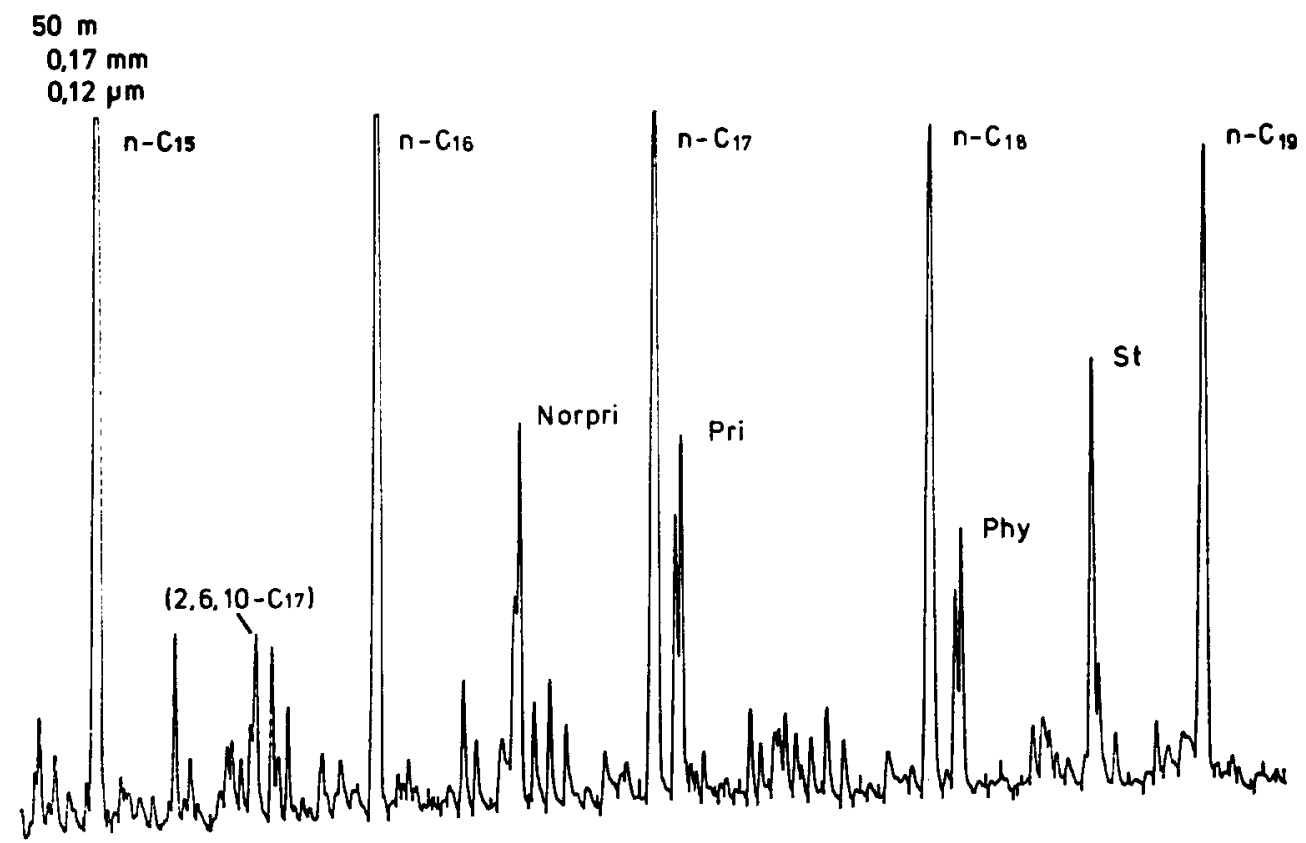

Fig. 6. Section of a glass-capillary gas chromatogram of the aliphatic and alicyclic fraction of Ekofisk crude oil after pre-separation from aromatics by high pressure liquid chromatography. The prominent peaks exhibit the normal alkanes ranging from n-pentadecane $\left(n-C_{15}\right)$ over 1-chlorohexadecane as internal standard to n-nonadecane $\left(n-C_{19}\right)$ as single peaks and the isoprenoid alkanes from 2,6,10-trimethyltetradecane $\left(2,6,10-C_{17}\right), 2,6,10$-trimethypentadecane (norpristane) and $2,6,10,14$-tetramethylpentadecane (pristane) to 2,6,10,14-tetramethylhexadecane (phytane) as double peaks. Experimental conditions: column dimensions $50 \mathrm{~m} \times 0.17 \mathrm{~mm}$; liquid phase thickness $0.12 \mu \mathrm{m}_{\mathrm{i}}$ splitless injection, splitless period $30 \mathrm{sec}_{\text {; }}$ carrier gas 2 bar $\mathrm{H}_{2 i}$ temperature programme $60^{\circ}-1^{\circ} \mathrm{C} \min ^{-1}-150^{\circ}$ 


\section{EFFECTS OF OIL POLLUTION UPON MARINE COMMUNITIES}

\section{Mammals}

Only mammals seem to be affected by particularized aged oil at the beach. Observations about the occurrence of deep ulcerations under oil-covered parts of dead animals have been reported (Vauk, 1973). The animals might have been contaminated creeping over cakes of oil which had been washed up. There are some vague reports about the disappearance and the death of Habour Seals, Grey Seals, Hair Seals and Sea Otters due to oil. Most of the reports contain unsupported remarks and statements and in most cases do not prove that oil was responsible for the effects. Several of these reports are summarized in the IMCO/FAO (1975) report. The problem is not truly reflected in the literature.

\section{Seabirds}

Seabirds are the first and most affected animals. The effects upon them are easily apparent since many (about 10-25\%) of the dead birds are washed up on the shore. Apart from the deaths resulting directly from massive oil pollution, it is known that soiling of the feathers leads to a loss of water-proofing and subsequent chilling and loss of buoyancy, as well as to the inability to obtain food. It is estimated that $150000-450000$ birds in the North Atlantic and in the North Sea die annually as a result of oil pollution.

There are toxic effects leading to the high mortality among self-cleaning birds due to ingestion. It was suggested that crude oil disturbs or destroys the extrarenal excretory nasal glands of seabirds. Birds are the only group of organisms that have suffered from oil pollution to the extent that not only limited local populations are killed, but that certain species or subspecies are threatened with extinction; this applies especially to puffins (Fratercula arctica), razorbills (Alca torda) and guillemots (Uria aalge).

The situation is made worse by the fact that several species, especially the auks, have an extremely low replacement rate in addition to the high early mortality from natural causes. Guillemots, for example, are only able to rear one young per year. Species with higher reproductive rates, on the other hand, seem to be able to withstand heavy and repeated losses, in that although high individual losses occur, the survival of the population is not endangered. But among such sober scientific considerations, the misery of the suffering creatures which was brought upon them by man should not be forgotten.

Oil damages seabirds only when it exists as a slick but never in particularized form. The use of dispersants could prove helpful in dispersing slicks more rapidly. However, it is questionable whether measures of this kind are sufficiently effective. Rescue and cleaning of birds are even less effective.

\section{Coral reefs}

Coral reefs provide protection against waves, preserving about 400 atolls, low tropical islands and thousands of miles of continental coastlines. Coral reefs are among the most biologically productive of all natural communities. 
Therefore, it is understandable that considerable fears exist that because of an oil spill the corals, as the chief reef builders, could be killed and the reef destroyed. Such fears must be taken seriously because it cannot be taken for granted that the reef community will ever restore itself. There are cases in the literature in which decades after coral death due to natural causes there was still little or no regeneration.

Judgement of the extent to which oil spills are really responsible for the death of corals is seldom unambiguous. A good summary is given by Johannes (1972). Experiments which were carried out in which animals in the laboratory were put directly into undiluted diesel oil, which naturally led to the death of the animals within a short time, can scarcely add to our knowledge. In absolute contradiction to repeatedly stated fears, Spooner (1969) found no damage to reef communities in Tarut Bay in Saudi Arabia, an area of chronic oil pollution. Many other investigations support this view. In 1978 Lopez concluded from case studies in Puerto Rico that coral reefs are least impacted owing to their subtidal nature and high energy. One wonders about the scientific basis for the many predictions that coral reefs are going to die and that coasts are endangered due to oil pollution.

If damage takes place it is likely to be expected from chronic effects in the sublethal range. Sublethal concentrations of the water-soluble part of Iranian crude oil induced immediate mouth opening in the Red Sea coral Stylophora pistallata followed by premature extrusion of planula larvae (Loya \& Rinkevich, 1979). This premature shedding decreases their viability and chances of successful settlement. The authors note that, at a chronically oil-polluted reef at the coral nature reserve of Eilat, almost no colonization of new colonies occurs, while high colonization is evident in reef areas free of oil pollution.

\section{Sublethal effects: Disturbance of chemical communication}

The greatest influences of oil pollution on marine life could lie in the disturbing of chemical communication. Chemical communication is one of the most ubiquitous and powerful controlling factors in the marine environment and is not restricted to higher organisms. The detection of food, feeding impulses, escape from predators, territory definition, selection of habitats, moulting, homing of migratory species, sex attraction, and other biological processes are regulated by extremely low concentrations of substances in sea water. Natural chemical signals such as pheromones that trigger these responses may be masked or mimicked by the presence of low concentrations of the water-soluble part of crude oil and oil fractions. It has long been known that lobsters are attracted to crude oil distillate fractions. They are very much attracted to kerosenesoaked bricks (Prudden, 1967, cited in Blumer, 1972). Thus an oil spill might attract lobsters away from their normal food and their normal habitat. Similar effects have been reported from fishes, snails and crabs.

Very interesting investigations on hydrocarbon-mediated effects in brown algae have been made recently. It was shown that these algae produce hydrocarbons acting as sexual pheromones (Müller, 1976, 1977; Müller \& Seferiadis, 1977; Müller et al., 1979). The effect takes place at an exceptionally high dilution. Steele (1977) found an extremely strong influence of the water-soluble fraction of crude oil on the fertilization of Fucus eggs when the exposure to oil occurred immediately prior to and during the 
release of gametes. Fertilization did not take place and thus no germination occurred even at the lowest concentration used. In contrast to this the growth of the fertilized egg was not influenced by an amount ten thousand times as great ( $2 \mathrm{ppm}$ ). Because of the possibility of interference with biotic cycles and disorientation in the natural habitat further investigations are necessary.

\section{FIELD STUDIES ON LONG-TERM EFFECTS}

\section{Chronic effects at low levels}

It is of considerable interest to see what is reported in field studies about the effects of chronic low level exposure of oil to marine life. Mertens (1976) summarized the results of five studies, some conducted with great effort; for example, the one in Timbalier bay cost 1.5 million dollars and involved 23 scientists for two years. The following results have been obtained.

No measurable effects were observed on indicators of the health of the local marine communities such as population levels of various organisms, species diversity, size, growth rate and reproducibility of various organisms. There was evidence of adverse effects such as abnormal growth and biomagnification of petroleum fractions in the food chain.

The same was found by Spies \& Davies (1979) in comparing the infaunal benthic community of a shallow natural oil seep near Santa Barbara (California, USA) and a nearby area without seepage but of similar depth and sediment type. There was a consistently larger but fluctuating density of organisms at the seep station. However, Shannon-Wiener diversity, Pielou's evenness and measures of dominance-diversity with estimates of graphical skewness and kurtosis were all similar for the two stations.

\section{Recovery potential of oiled environments after major oil spills}

From the ecological point of view, much more important than the initial damage is the length of time the environment remains in the damaged state, that is, how long it takes until the environment recovers. In 1976, at a symposium in Halifax with the topic "Recovery Potential of Marine Northern Environments" (Stevenson, 1978) fundamental data about the regeneration of marine communities after oil spills have been compiled.

Man-made oil pollution was compared with other man-made influences on the destruction of biological communities. An extreme case is the cutting down of the forests of the Mediterranean in antiquity. Here 2000 years have not been enough to restore the original condition. After forest fires the original condition is restored only after decades. The Thames, on the other hand, showed a marked recovery within 5 years after improvement of sewage facilities.

In contrast to the long-term effects of such terrestrial environmental impacts, recovery of marine communities after oil pollution is possible in a reasonably short time. Even after extremely heavy pollution, it usually only takes $2-5$ years before a state is reached which is within the natural variation of the particular environment. Consult Stevenson (1978) for results and details. 


\section{CARCINOGENIC SUBSTANCES}

Considerable attention has been devoted to the fear that carcinogenic substances introduced into the sea by an oil spill could cause cancer in humans. The concentration of carcinogenic substances in crude oil, however, is extremely low. Graf \& Winter (1968) found maximum values of $1800 \mathrm{mg}$ of 3,4-benzpyrene/ton of crude oil. Blumer created some confusion by miscalculating their data by the factor of 1000 .

Only ingestion with food can be of significance to humans. Strongly oiled and tainted seafood is unacceptable as food.

There is information about bioconcentration, but not about biomagnification of potentially carcinogenic substances in the food chain. It could be proven (Anderson, 1973) that oiled mussels are capable of eliminating the greater part of the potentially carcinogenic substances within some days, when placed in unpolluted water.

It had been demonstrated, that 3,4-benzpyrene and other polycyclic aromatic hydrocarbons are synthesized by organisms (ZoBell, 1971) and that these substances are common worldwide in soil, water, plants and animals. Organisms have a natural background level and thus humans regularly consume minute amounts of these substances.

Many marine and non-marine food substances have been analyzed. Only very rarely did seafood from oil-spill areas have values of 3,4-benzpyrene and benzanthracene that were higher than those in other foodstuffs such as kale and salad.

We do know that no absolutely safe threshold value exists and we must be critical of even the smallest amount which increases the load in man and hence increases the chances of illness. "However benzo(a)pyrene and other PCAH are relatively abundant in many foods including fresh vegetables and smoked foods and it would appear that the risk to the health of a member of the public by spillage of oil at sea is probably far less than that which he usually encounters by eating a range of popular foods" (King, 1977).

\section{CONCLUSION}

In conclusion we state: (1) Oil pollution and its effects are limited in scale, time and space. (2) The magnitude of the effects at the coast depends on the period of aging of the oil, the distance from the coast and the energy-level of the beach. (3) There is no increased risk of cancer due to polycyclic aromatic hydrocarbons derived from crude oil in marine foodstuffs. (4) The greatest gaps in our knowledge exist in regard to atmospheric input, actual microbial degradation rates in the open sea, disturbance of chemical communication of organisms and whether (if yes, to what extent) pelagic oil (tar particles) reaches the bottom of the deep sea.

\section{LITERATURE CITED}

American Institute of Biological Sciences, 1976. Sources, effects and sinks of hydrocarbons in the aquatic environment. Washington, D.C., $578 \mathrm{pp}$.

American Petroleum Institute, 1977. 1977 Oil spill conference. Washington D.C., 640 pp.

Anderson, J. W., 1973. Uptake and depuration of specific hydrocarbons from oil by bivalves Rangia cuneata and Crassostrea virginica. In: Background papers for a workshop on inputs, fates and effects in the marine environment, Arlie, Virginia 21-25 May 1973. National Academy Sciences, Washington D. C. 2, 690-708. 
Atlas, R. M. \& Bartha, R., 1973. Biodegradation of oil in seawater: limiting factors and artificial stimulation. In: The microbial degradation of oil pollutants. Ed. by D. G. Ahearn \& S. P. Meyers. Louisiana State University, Baton Rouge, L. A., 147-152.

Bartha, R. \& Atlas, R. M., 1977. The microbiology of aquatic oil spills. - Adv. appl. Microbiol. 22, 225-266.

Blackman, R. A. A., Franklin, F. L., Norton, M. G. \& Wilson, K. W., 1978. New procedures for the toxicity testing of oil slick dispersants in the United Kingdom. - Mar. Pollut. Bull. 9, 234-238.

Blumer, M., 1972. Oil contamination and the living resources of the sea. In: Marine pollution and sea life. Ed. by M. Ruivo. Fishing News Books, London, 476-481.

BP Ltd., 1979. BP statistical review of the world oil industry 1978. British Petroleum Company Limited, London, $33 \mathrm{pp.}$

Bunt, J. S., 1975. Primary productivity of marine ecosystems. In: Primary productivity of the biosphere. Ed. by H. Lieth \& R. H. Whittaker, Springer, Berlin, 169-183.

Butler, J. N., Morris, B. F. \& Sass, J., 1973. Pelagic tar from Bermuda and the Sargasso Sea. Bermuda Biological Station for Research, Bermuda, 346.

Butler, J. N. \& Morris, B. F., 1974. Quantitative monitoring and variability of pelagic tar in the North Atlantic. In: Marine pollution monitoring (Petroleum). Ed. by R. C. Junghaus. U.S. Govt Print Off., Washington, D.C., 316 pp. (NBS Special Publ. 409).

Cox, R. E., Maxwell, J. R., Ackman, R. G. \& Hooper, S. N., 1972. Stereochemical studies of acyclic isoprenoid compounds. III. The stereochemistry of naturally occurring (marine) $2,6,10,14$ tetramethylpentadecane. - Can. J. Biochem. 50, 1238-1241.

Crow, S. A., Meyers, S. P. \& Ahearn, D. G., 1974. Microbiological aspects to petroleum degradation in the aquatic environment. - La mer 12 (2), 95-112.

Dastillung, M. \& Albrecht, P., 1976. Molecular test for oil pollution in surface sediments. - Mar. Pollut. Bull. 7, 13-15.

Der Spiegel, 1979. Ol: Streit um die letzten Tonnen und Fässer. - Der Spiegel 33 (24), 19-26.

Dixon, T. R., 1977. Oil pollution precautions on Kent coast. - Mar. Pollut. Bull. 8, 195.

Floodgate, G. D., 1972. Biodegradation of hydrocarbons in the sea. - Water Pollut. Microbiol. 3, $153-171$.

Fuhs, W. W., 1961. Der mikrobielle Abbau von Kohlenwasserstoffen. - Arch. Mikrobiol. 39, $374-422$

Gebelein ${ }_{t}$ C. D., 1973. Sedimentation processes involving hydrocarbons in the marine environment. In: Background papers for a workshop on inputs, fates and effects of petroleum in the marine environment, Arlie, Virginia 21-25. 5. 1973. National Academy of Sciences, Washington, D. C., $2,462-474$.

Gerlach, S. A., 1976. Meeresverschmutzung. Springer, Berlin, 154 pp.

Graf, W. \& Winter, C., 1968. 3,4 Benzpyren in Erdöl. - Arch. Hyg. Bakt. 152, 289-293.

Gundlach, E. R. \& Hayes, M. L., 1978. Investigation of beach processes. In: The Amoco Cadiz oil spill. Ed. by W. N. Hess. Washington (NOAA/EPA Spec. Rep.).

Gunkel, W., 1967. Experimentell-ökologische Untersuchungen über die limitierenden Faktoren des mikrobiellen Ölabbaues im marinen Milieu. - Helgoländer wiss. Meeresunters. 15, 210-225.

Gunkel, W., 1968. Bacteriological investigations of oil-polluted sediments from the Cornish coast following the "Torrey Canyon" disaster. - Field Stud, 2 (Suppl.), 151-158.

Gunkel, W., 1973. Distribution and abundance of oil-oxidizing bacteria in the North Sea. In: The microbial degradation of oil pollutants. Ed. by D. G. Ahearn \& S. P. Meyers. Louisiana State University, Baton Rouge, L.A., 127-129.

Gunkel, W., Gassmann, G., Oppenheimer, C. H. \& Dundas, I., 1980. Preliminary results of baseline studies of hydrocarbons and bacteria in the North Sea: 1975, 1976 and 1977. In: Ponencias del simposio internacionalen: Resistenica a los antibioticos y microbiologia marina. Santiago de Compostela, 223-247.

Hardy, R., Mackie, P. R. \& Whittle, K. J., 1977. Hydrocarbons and petroleum in the marine ecosystem - a review. - Rapp. P.-v. Réun. Cons. int. Explor. Mer 171, 17-26.

Hellmann, H., 1978. Neue Untersuchungsergebnisse zur Wirksamkeit und zur potentiellen Schadwirkung von Chemikalien zur Ölbekämpfung. - Tenside 15, 205.

Horvath, R. S., 1972. Microbial co-metabolism and the degradation of organic compounds in nature. - Bact. Rev. 36 (2), 146-155. 
IMCO/FAO/UNESCO/WMO/WHO/LAEA/UN, Joint Group of Experts on the Scientific Aspects of Marine Pollution (GESAMP), 1977. Impact of oil on the marine environment. - Rep. Stud. GESAMP 6, 1-250.

Johannes, R. E., 1972. Coral reefs and pollution. In: Marine pollution and sea life. Ed. by M. Ruivo. Fishing News Books, London, 364-375.

King, P. J., 1977. An assessment of the potential carcinogenic hazard of petroleum hydrocarbons in the marine environment. - Rapp. P.-v. Réun. Cons. int. Explor. Mer. 171, 202-211.

Koons, C. B. \& Monaghan, P. H., 1976. Input of hydrocarbons from seeps and recent biogenic sources. In: Sources, effects and sinks of hydrocarbons in the marine environment. The American Institute of Biological Sciences, Washington D. C., 85-107.

Koons, C. B. \& Wheeler, R. B., 1977. Inputs, fate, and effects of petroleum in offshore Norwegian waters. - Exxon Production Res. Comp. Spec. Rep. EPR. 28EX, 77.

Linden, van der, A. C., 1978. Degradation of oil in the marine environment. In: Developments in biodegradation of hydrocarbons. Ed. by R. J. Watkinson. Science Publ., London, 1, 165-200.

Lopez, S. M., 1978. Ecological significance of petroleum spillage in Puerto Rico. In: Proceedings of conference on assessment of ecological impacts of oil spills. Keystone, Col., 17 pp.

Loya, Y. \& Rinkevich, B., 1979. Abortion effects in corals induced by oil pollution. - Mar. Ecol, Prog. Ser. 1, 77-80.

Lytle, J. S., Lytle, T. F., Gearing, J. N. \& Gearing, P. J., 1979. Hydrocarbons in benthic algae from the eastern Gulf of Mexico. - Mar. Biol. 51, 279-288.

McIntyre, A. D. \& Whittle, K. J., 1977. Petroleum hydrocarbons in the marine environment. - Rapp. P.-v. Réun. Cons. int. Explor. Mer 171, 1-230.

McKenzie, P. \& Hughes, D. E., 1976. Microbial degradation of oil and petrochemicals in the sea. In: Microbiology in agriculture, fisheries and food. Ed. by F. A. Skinner \& J. D. Carr. Academic Press, London, 91-108.

Mertens, E. W., 1976. The impact of oil on marine life: a summary of field studies. In: Sources, effects and sinks of hydrocarbons in the aquatic environment. The American Institute of Biological Sciences, Washington, D. C., 507-514.

Miller, J. W., 1973. A multiparameter oil pollution source identification system. - Environmental Protection Agency report. EPA-R2-73-221, Washington, 1-173.

Müller, D. G., 1976. Quantitative evaluation on sexual chemotaxis in two marine brown algae. $-Z$. Pflanzenphysiol. 80, 120-130.

Müller, D. G., 1977. Chemical basis of sexual approach in marine brown algae. In: Marine natural products chemistry. Ed. by D. J. Faulkner \& W. H. Fenical. Plenum Press, New York, 351-360.

Müller, D. G. \& Seferiadis, K., 1977. Specificity of sexual chemotaxis in Fucus serratus and Fucus vesiculosus (Phaeophyceae). - Z. Pflanzenphysiol. 84, 85-94.

Müller, D. G., Gassmann, G. \& Lüning, K, 1979. Isolation of a spermatozoid releasing and attracting substance from female gametophytes of Laminaria digitata (Huds.) Lamour (Phaeophyta). Nature, Lond. 279 (5712), 430-431.

National Academy of Sciences, 1975. Petroleum in the marine environment. Washington, D.C., $107 \mathrm{pp}$.

Oppenheimer, C. H., Gunkel, W. \& Gassmann, G., 1977. Microorganisms and hydrocarbons in the North Sea during July-August 1975. Proceedings 1977 Oil Spill Conference Washington, 593-609.

Owens, E. H., 1978. Mechanical dispersal of oil stranded in the littoral zone. - J. Fish. Res. Bd Can. $35,563-572$.

Patience, R. L., Rowland, S. J. \& Maxwell, J. R., 1978. The effect of maturation on the configuration of pristane in sediments and petroleum. - Geochim. Cosmochim. Acta 42, 1871-1875.

Perry, J. J., 1979. Microbial cooxidations involving hydrocarbons. - Microbiol. Rev. 43, 59-72.

Ruivo, M., 1972. Marine pollution and sea life. Fishing News Books, London, 624 pp.

Spies, R. B. \& Davis, P. H., 1979. The infaunal benthos of a natural oil spill in the Santa Barbara Channel. - Mar. Biol. 50, 227-237.

Spooner, M., 1969. Oil spill in Tarut Bay, Saudi Arabia. - Mar. Pollut. Bull. 1, 166-167.

Steele, R. L., 1977. Effects of certain petroleum products on reproduction and growth of zygotes and juvenile stages of the alga Fucus edentatus DeLa Pyl (Phaeophyceae: Fucales). In: Fate and 
effects of petroleum hydrocarbons in marine ecosystems and organisms. Ed. by D. A. Wolfe. Pergamon Press, Oxford, 138-142.

Stevenson, J. C. (Ed.), 1978. Recovery potential of oiled marine nothern environments. - J. Fish.,Res. Bd Can. 35, 499-796.

Vauk, G., 1973. Beobachtungen am Seehund (Phoca vitulina L.) auf Helgoland. - Z. Jagdwiss. 19, $117-121$

Went, F. W., 1960. Organic matter in the atmosphere and its possible relation to petroleum formation. - Proc. nat. Acad. Sci. U.S.A. 46, 212-221.

Whittle, K. J., Hardy, R. \& McIntyre, A. D., 1978. Scientific studies at future oil spill incidents in the light of past experience. - C. M. - I.C.E.S. $E 38$.

Wolfe, D. A. (Ed.), 1977. Fate and effects of petroleum hydrocarbons in marine organisms and ecosystems. Pergamon Press, Oxford, 478 pp.

ZoBell, C. E., 1964. The occurrence, effects and fate of oil polluting the sea. Pergamon Press, Oxford, $85-119$

ZoBell, C. E., 1971. Sources and biodegradation of carcinogenic hydrocarbons. American Petroleum Institute, Washington, D.C., 441-451.

ZoBell, C. E., 1973. Microbial degradation of oil: present status, problems and perspectives. In: The microbial degradation of oil pollutants. Ed. by D. G. Ahearn \& S. P. Meyers. Louisiana State University, Baton Rouge, L.A., 3-16. 